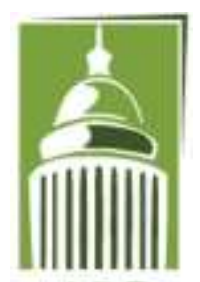

ARF

\section{Global Proceedings Repository \\ American Research Foundation}

ISSN 2476-017X

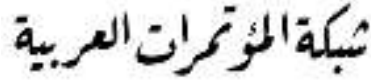

http://arab.kmshare.net/

Available online at http://proceedings.sriweb.org

The 10th International Scientific Conference

Under the Title

"Geophysical, Social, Human and Natural Challenges in a Changing Environment"

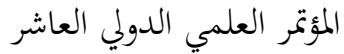

$$
\begin{aligned}
& \text { تحت عنوان "التحديات الجيوفيزيائية والاجتماعية والانسانية والطبيعية في بيئة متغيرة" } \\
& 25 \text { - } 26 \text { يوليو - تموز } 2019 \text { - اسطنبول - تركيا }
\end{aligned}
$$

http://kmshare.net/isac2019/

\title{
Study biochemical characterization and Prevalence antibiotic resistance of bacterial isolated from computer keyboards
}

\author{
Ali.F.Hussein a , Nada .j. Dawood b, Tagreed. A. Obuid ${ }^{\mathrm{c}}$ \\ a, b, c, Southern Technical University, Technical Institute Basra, Iraq \\ a.faisal@stu.edu.iq
}

\begin{abstract}
The study target was to survey the incidence of microbe's contamination and the Diffusion of Species of computers key from computer labs of some department technical institute of (Nursing, Pathological Analysis, Electronic, electricity) and some hospitals in Basra (Ports General Hospital, Shifa General Hospital), this descriptive study was done on seventy five computers keyboards during 2018 2019. Collected Samples from computers keyboards Samples and Cultivated on NA (Nutrient agar) and (MA) MacConkey Agar and growing bacteria were identified based on their biochemical and morphology properties 70 eleventh colonies out of Seventy five samples were contaminated with bacteria. The most pollution pertained to (Gr+) Gram positive bacteria (99\%). The most isolated bacteria were Bacillus, the high level from contamination rates were found on computers keyboards of which were (Shifa General Hospital).
\end{abstract}

Keywords: computer microorganism, Bacterial contamination, computers keyboard surfaces Antibiotic resistance bacteria. 


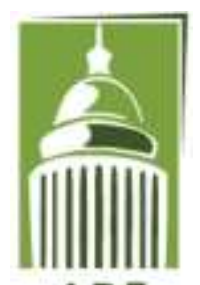

ARF

\section{Global Proceedings Repository \\ American Research Foundation}

ISSN 2476-017X

Available online at http://proceedings.sriweb.org

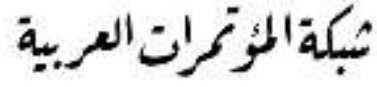

http://arab.kmshare.net/

\section{Introduction}

Pathogens Bacterial are colonized on animate and inanimate objects, but most people do not recognize that microorganisms are found on many public objects in the in the open air, in their offices and even in their homes [1]. The Computer keyboards at helps spread pathogenic microbes. The Computers are ubiquitous have contaminated with potentially, pathogenic microorganisms [2,3]. Many bacteria have been isolated from computer Computers are ubiquitous in the health care centers and have been shown to be contaminated with potentially pathogenic . These healthcare-associated infections are an important cause of morbidity and mortality in hospitals and in each year more than 2 million patients acquire healthcareassociated infections, resulting in 90,000 deaths and healthcare costs that are estimated to exceed $\$ 5$ billion [4]. Various bacteria is isolated from computers key and in worldwide including developed countries, the bacterial pathogens are colonized on human host and inanimate objects .In different literatures from nosocomial pathogens indicated that Gram-positive bacteria, such as S.aureus, Enterococcus species, and Streptococcus pyogenic survive for months on computer keyboards and mice [2, 5] . Many Gram-negative bacteria, such as, Escherichia coli, Klebsiella species, Acenitobacter species and Pseudomonas aeruginosa can survive On computer keyboards and mice surfaces even for months [5]. The degree to which computers keyboards and mice are contaminated is different. One study reported, for example studies from 100 keyboards in" 29 clinical areas, 95\%" keyboards were positive for microorganisms [6]. The Based on the level of pathogen on Computer keyboards $(25 \%)$ of keyboards in hospitals carry pathogens microorganisms. the double that of other commonly touched surfaces, Leading to the transmission of pathogenic microbes and that contact with contaminated computer keyboards might serve as a mechanism for contaminating the hands of healthcare health care workforces with potential pathogens, there by leading to cross-contamination of patients.

Thus, impact on human health, the present of study has been planned with following aims and objectives: 1-This study to identify the types of bacteria, which could be the source of contamination from computers key.

2. To isolate characterize bacteria from computer keyboards.

3-To study biochemical test to all isolates.

4-To study antibiotic resistance behavior among isolated strains. 


\section{Global Proceedings Repository \\ American Research Foundation}

ISSN 2476-017X

Available online at http://proceedings.sriweb.org

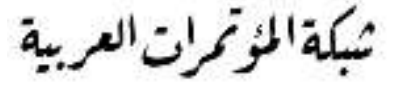

http://arab.kmshare.net/

ARF

\section{MATERIAL AND METHOD}

All the media and glassware were sterilized at pressure of $15 \mathrm{lb}$. inch ${ }^{-2}$ and temperature of $120^{\circ} \mathrm{C}$ for 20 minutes in autoclave.

\subsection{Instrument \& tools}

1- Autoclave

2- Microscopy

3- Wire loop

4- Benzene burner

5- Pitre dish

6- Glassware

7- Incubator

8-Hood

(Test-tube, beaker, conical flask, petri dish, Glass slide).

\section{2 media uses $(\mathrm{g} / \mathrm{l})$}

1- Nutrient agar

2- Nutrient Broth

3- MacConkey Broth

4- Mueller Hinton agar

5- TSI Agar

6-Simmon's citrate agar

\subsection{REAGENTS AND BUFFERS}

1- Gram staining solution

2- Kovac's reagent

3- Barrit's reagent Solution A\&B

4- Methyl Red solution

Antibiotic discs used:-

Methicillin(ME10), Linomycin (L10), Erythromycin (E15), Tobramycin (TOB30), Metronidazole (MET30 ), Novobiocin (NV30), Trimethoprim (TRS15), Azithromycin (AZM15),Rifampin(RAS),Streptomycin(S10).

\subsection{Sample collection}

The Sample collection from the surfaces of 75 computer keyboards were collected using sterile cotton swabs (Ports General Hospital(HM), Shifa General Hospital(HS) and each of the computer lab departments (Nursing(LN), Pathological Analysis(LN), Electronic(LE), electricity(Le ).The samples were transferred to the laboratory the Bacteria was isolated by spread method on the nutrient agar and MacConkey (Figure2)

Isolation of bacteria: 


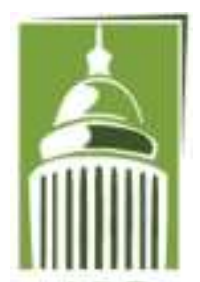

AR F

\section{Global Proceedings Repository \\ American Research Foundation}

ISSN 2476-017X

Available online at http://proceedings.sriweb.org

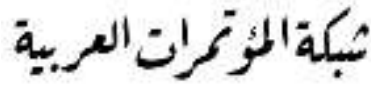

http://arab.kmshare.net/

\section{Methods:}

The total bacterial count (TBC) was Identify them according by the standard methods: The Bacteria was isolated from by streak method. The colonies incubation for $\left(24\right.$ to 28 hour at $\left.37{ }^{\circ} \mathrm{C}\right)$. The number of positive cultures were used to determine the total bacterial count /g. Cultures were plated on selective media like: (MA) MacConkey Agar to isolate single colonies, which were determines by correlating colonial appearance, Gram stain, and Antibiotic susceptibility was determined by disk distribution according to standard microbiological procedures. Briefly the bacterial suspensions were plated on media Mueller Hinton agar, and after addition of the antibiotic-containing disks. The plates were incubated for ( 24 to 28 hour at $37^{\circ} \mathrm{C}$ ). Diameters of the growth inhibition zone were used to Identify, the clinical resistance / susceptibility in to Antibiotics. Disks of ten antimicrobial chemotherapeutic agents : Methicillin(ME10), Linomycin (L10), Erythromycin(E15), Tobramycin(TOB30),Metronidazole (MET30), Novobiocin (NV30), Trimethoprim(TRS15), Azithromycin(AZM15), Rifampin(RAS), Streptomycin(S10).

\subsection{RESULTS AND DISCUSSION}

The total of eleventh colonies bacterial cultures were isolated from75 samples computer keyboard (Figure1). tentatively identified as 10 bacteria give Gram positive on the basis of Gram's staining Out of 1 Gram negative bacteria, 6 were Bacillus and 5 were Cocci Colony characteristics of the isolates are presented in (Table1\&Figure 4), The color of colonies was generally white, yellow and brown. The

morphological, cultural and biochemical characteristics in accordance with Bergey's Manual of Determinative Bacteriology [7].The isolates were further characterized biochemically. All isolates negative for Indole, all isolate negative for voges prauskeur test , gave 8 positive methyl red test, and 5 positive for Simon's citrate test. (Table 1\&Figure3B).

All the bacterial isolates from six sources were tested for utilization of different Isolates tested for triple sugar iron in that acid butt, acid slant, gas produced and no H2S production was observed in, 5 isolates yellow color slant and 6 isolates red color slant., 9 isolates yellow color butt and 2 isolates red color butt, 5 gas produced and no $\mathrm{H} 2 \mathrm{~S}$ production. (Table2\&Figure $3 \mathrm{~A}$ ).

\subsection{ANTIBIOTIC RESISTANCE}

A total of 10 common antibiotics were used Antibiotic resistance/sensitivity profiles of bacterial strains namely (Bacilli ssp, Cocci), against common antimicrobial drugs varied considerably, the antibiotic sensitivity behavior of the strains were determined by disc diffusion method as described by Bauer et al., (1966) [8]. A high level of resistance against ME10 (77\%) and E15 (33) \% was observed. 33\%were resistant to L10, 22\%to (S10, NV30, TOB10, NET30\&RA5), and low level resistance $11 \%$ to TRS10. (Table4\&Figure5). 


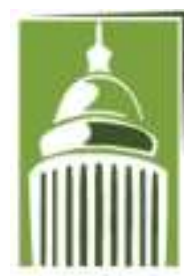

ARF

\section{Global Proceedings Repository \\ American Research Foundation}

ISSN 2476-017X
شبكة المؤرخرات العربية

http://arab.kmshare.net/

Available online at http://proceedings.sriweb.org

\section{Conclusion:}

Computers keyboards in both non-hospital and hospital contain harbored microbes such as bacillus and cocci. Statistical analysis revealed a homogeneity in the isolation of microorganisms; there was however significant difference in isolation of cocci . The computers keyboards in non-hospital setting as against those in hospitals setting, Thus presence of pathogenic microbes on computers keyboards is a cause of concern. Since computer keyboards are provided a surface for colonization , infection control guidelines must aim appropriate adequate hand hygiene and surface of computers keyboards disinfection and awareness on cleaning of such surfaces.

\section{Recommendations}

1- The computer keyboard must be sterilized before using the computer with antiseptics and medical alcohol to get rid of bacterial contamination as well as using warm air to remove the food residues that cause the growth of microorganisms.

2- Don't eat food while working on computer where parts of food can fall on the keyboards and cause the growth microorganisms.

3- Clean the keyboard daily with disinfectant paper.

4- People should wash their hands well after getting out of toilets.

5- Wash the hands frequently and don't touch the nose and eye director while use

The keyboard.

Table 1.Morphological and Biochemical characteristics to all bacteria isolated from keyboard computer

\begin{tabular}{|c|c|c|c|c|c|c|c|c|c|c|c|}
\hline Morphological\& Biochemical & LN1 & LN2 & LA1 & LA2 & LE & Le & HM1 & HM2 & HS1 & HS2 & HS3 \\
\hline Colony Morphology & B & B & C & B & B & B & C & C & C & C & B \\
\hline Colony colors & w & y & w & y & w & y & w & b & y & y & w \\
\hline Gram Stain & + & + & + & + & + & + & + & + & - & + & + \\
\hline Indol test & - & - & - & - & - & - & - & - & - & - & - \\
\hline Vogues - proskaeur test & - & - & - & - & - & - & - & - & - & - & - \\
\hline Methyl red test & - & + & - & + & + & + & + & + & - & + & + \\
\hline
\end{tabular}

Indicates positive reaction. $\mathrm{B}=\mathrm{Bacillus}, \mathrm{C}=\mathrm{Cocci}, \mathrm{y}=$ yellow color, ' ${ }^{\prime}-$ Indicates negative reaction, ',$+ \mathrm{w}=$ white color, $\mathrm{b}=$ brown color 


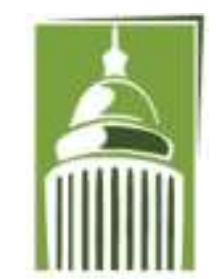

ARF

\section{Global Proceedings Repository \\ American Research Foundation}

ISSN 2476-017X
شبكة المؤرخراتِ العربية

http://arab.kmshare.net/

Available online at http://proceedings.sriweb.org

Table2.Utilization of TSI (Triple sugar iron test) by the bacterial isolates from keyboard computer.

\begin{tabular}{|c|c|c|c|c|c|}
\hline Isolates & slop & Butt & Gas & $\mathrm{H} 2 \mathrm{~s}$ & Tentative identification \\
\hline LN1 & $\mathrm{Y}$ & Y & + & - & BACTERA ISOLATED FROM computer lab NURSING department \\
\hline LN2 & $\mathrm{R}$ & $\mathrm{R}$ & - & - & BACTERA ISOLATED FROM computer lab NURSING department \\
\hline LA1 & $\mathrm{R}$ & $\mathrm{R}$ & - & - & BACTERA ISOLATED FROM computer lab Pathological Analysis \\
\hline LA2 & $\mathrm{R}$ & Y & - & - & BACTERA ISOLATED FROM computer lab Pathological Analysis \\
\hline LE & $\mathrm{R}$ & Y & - & - & BACTERA ISOLATED FROM computer lab Electronic \\
\hline Le & $\mathrm{R}$ & Y & - & - & BACTERA ISOLATED FROM computer lab electricity \\
\hline HM1 & Y & Y & + & - & BACTERA ISOLATED FROM computer lab Ports General Hospital \\
\hline HM2 & $\mathrm{R}$ & Y & - & - & BACTERA ISOLATED FROM computer lab Ports General Hospital \\
\hline HS1 & $\mathrm{Y}$ & Y & + & - & BACTERA ISOLATED FROM computer lab Shifa General Hospital \\
\hline HS2 & $\mathrm{Y}$ & Y & + & - & BACTERA ISOLATED FROM computer lab Shifa General Hospital \\
\hline HS3 & Y & Y & + & - & BACTERA ISOLATED FROM computer lab Shifa General Hospital \\
\hline
\end{tabular}

‘-'Indicates negative reaction, '+ 'Indicates positive reaction, $\mathrm{R}=$ red color, $\mathrm{Y}=$ yellow color 
ISSN 2476-017X

Available online at http://proceedings.sriweb.org

Table3.Antibiotic resistance/sensitivity profile of Gram-negative and Gram -positive bacteria.

\begin{tabular}{|c|c|c|c|c|c|c|c|c|c|c|}
\hline \multirow[t]{2}{*}{ Isolates } & \multicolumn{10}{|c|}{ Diameter of inhibition zone (in $\mathrm{mm}$ ) of antibiotic } \\
\hline & ME10 & L10 & E15 & TOB 10 & NET30 & NV30 & TRS 10 & AZM 15 & RA5 & $\mathrm{S} 10$ \\
\hline LN1 & 10 & 18 & $\mathrm{r}$ & $\mathrm{r}$ & 20 & 20 & 22 & 18 & 20 & 22 \\
\hline LN2 & $\mathrm{r}$ & 20 & 10 & 24 & 19 & 17 & 30 & 20 & 16 & 23 \\
\hline LA1 & $\mathrm{r}$ & $\mathrm{r}$ & 12 & 22 & 18 & $\mathrm{r}$ & 21 & $\mathrm{r}$ & $\mathrm{r}$ & 27 \\
\hline LA2 & 12 & 15 & $\mathrm{r}$ & 21 & 23 & 23 & 20 & 13 & 16 & 30 \\
\hline LE & $\mathrm{r}$ & $\mathrm{r}$ & 10 & 20 & 24 & 19 & 19 & $\mathrm{r}$ & $\mathrm{r}$ & 12 \\
\hline Le & $\mathrm{r}$ & $\mathrm{r}$ & 11 & $\mathrm{r}$ & 22 & 15 & 30 & 12 & 17 & 15 \\
\hline HM1 & 15 & 11 & $\mathrm{r}$ & 19 & 20 & 20 & 25 & $\mathrm{r}$ & 19 & $\mathrm{r}$ \\
\hline HM2 & 16 & 22 & 20 & 20 & 17 & 29 & 23 & 10 & 20 & 16 \\
\hline HS1 & $\mathrm{r}$ & 24 & 21 & 23 & $\mathrm{r}$ & $r$ & 24 & $\mathrm{r}$ & 28 & 22 \\
\hline HS2 & 19 & 12 & $\mathrm{r}$ & 20 & 20 & 10 & 20 & $\mathrm{r}$ & 27 & 16 \\
\hline HS3 & $r$ & 10 & $r$ & 20 & $\mathrm{r}$ & 12 & $\mathrm{r}$ & 19 & 22 & $\mathrm{r}$ \\
\hline
\end{tabular}

' $r$ 'Indicates antibiotic resistance, Abbreviation used: Methicillin(ME10), Linomycin (L10), Erythromycin( E15),

Tobramycin (TOB30), Metronidazole (MET30), Novobiocin (NV30), Trimethoprim(TRS15), Azithromycin(AZM15),

Rifampin (RAS), Streptomycin(S10). 


\section{Global Proceedings Repository \\ American Research Foundation}

ISSN 2476-017X

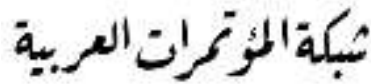

http://arab.kmshare.net/

Available online at http://proceedings.sriweb.org

Table 4.Antibiotic resistance in bacterial isolates from computer keyboards.

\begin{tabular}{|c|c|c|c|}
\hline S. No & Antibiotic discs & Concentration $\boldsymbol{\mu g} / \mathbf{d i s c})$ & \% of Resistance \\
\hline 1 & Metronidazole & ME10 & $77 \%$ \\
\hline 2 & Linomycin & L10 & $33 \%$ \\
\hline 3 & Erythromycin & E15 & $55 \%$ \\
\hline 4 & Tobramycin & TOB30 & $22 \%$ \\
\hline 5 & Methicillin & NET30 & $22 \%$ \\
\hline 6 & Novobiocin & NV30 & $11 \%$ \\
\hline 7 & Trimethoprim & TRS10 & $55 \%$ \\
\hline 8 & Azithromycin & AZM15 & $22 \%$ \\
\hline 9 & Rifampin & RA5 & $22 \%$ \\
\hline 10 & Streptomycin 10 & S10 & \\
\hline
\end{tabular}




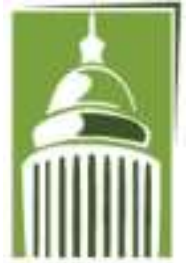

ARF
Global Proceedings Repository

American Research Foundation

ISSN 2476-017X

Available online at http://proceedings.sriweb.org

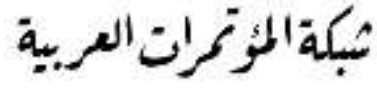

http://arab.kmshare.net/

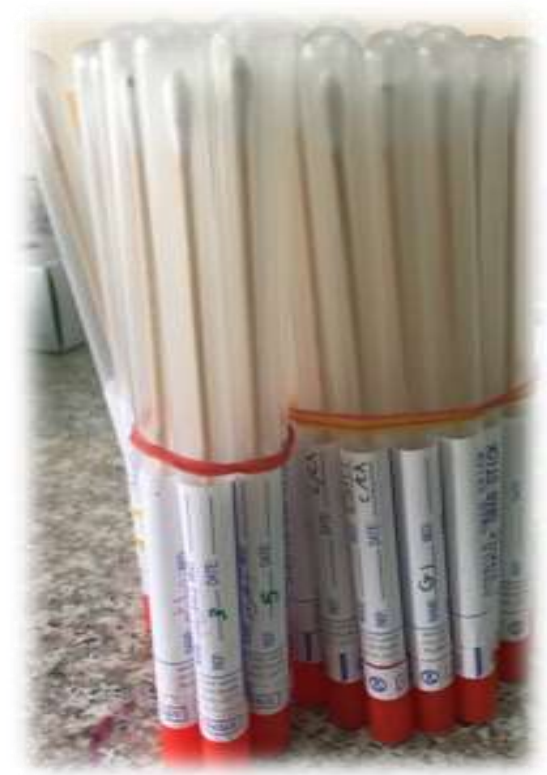

Figure 1: Samples collection by sterile cotton swabs.

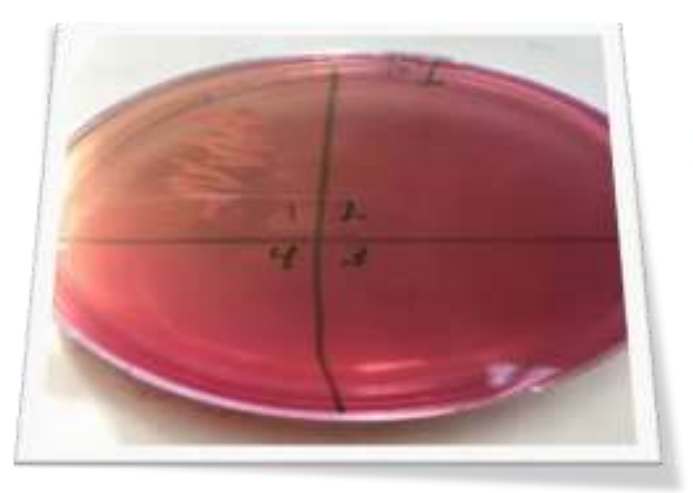

(A)

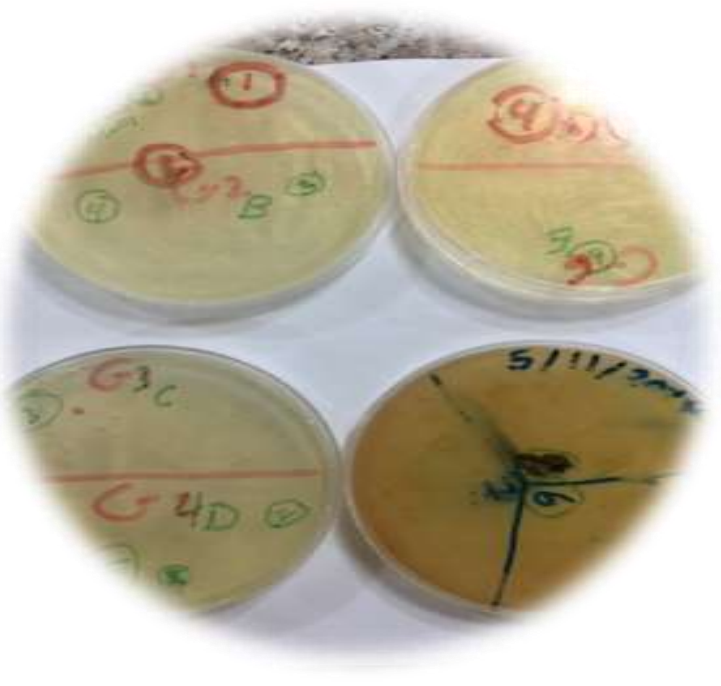

(B)

Figure 2: Bacterial colonies on nutrient agar (A) and MacConkey agar (B) plate. 
Available online at http://proceedings.sriweb.org

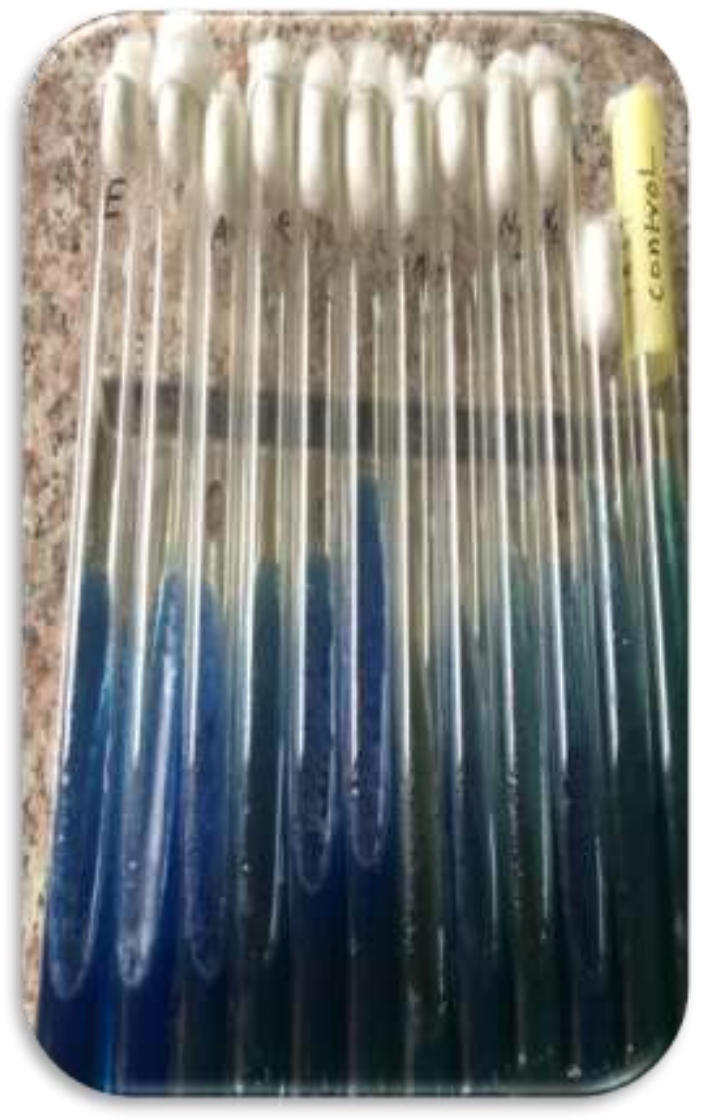

(A)

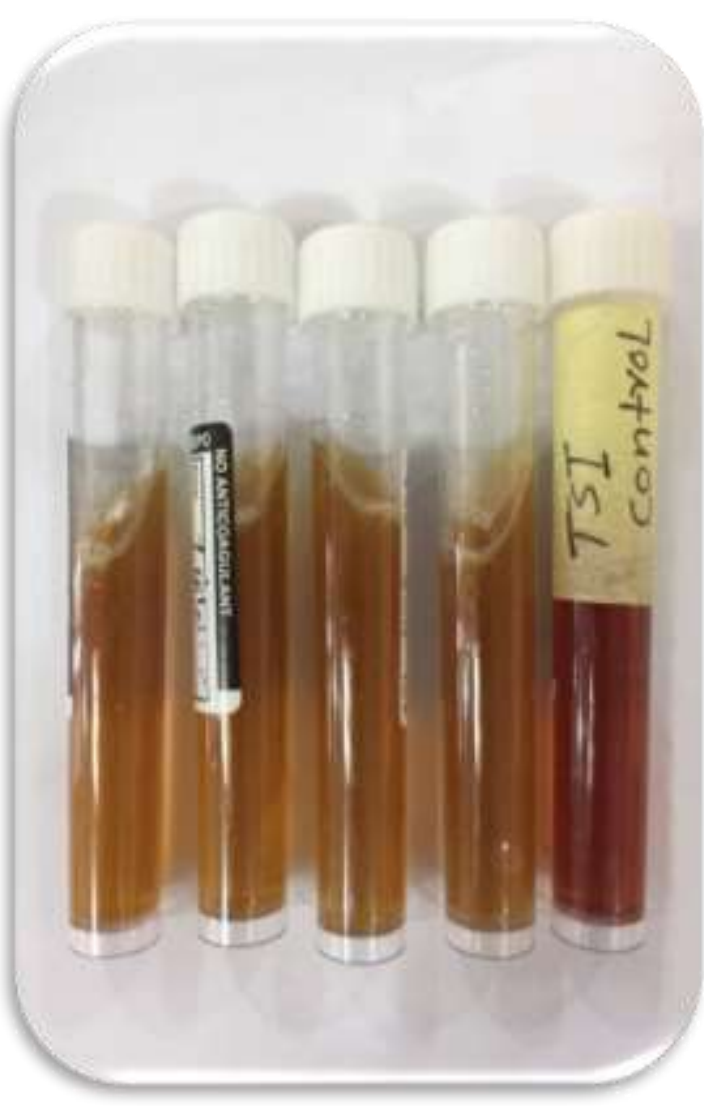

(B)

Figure3: (A) TSI test \& (B) Citrate utilization 


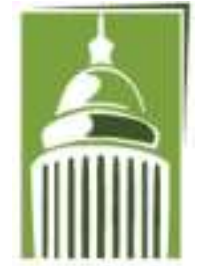

ARF

\section{Global Proceedings Repository \\ American Research Foundation}

ISSN 2476-017X

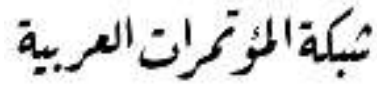

http://arab.kmshare.net/

Available online at http://proceedings.sriweb.org

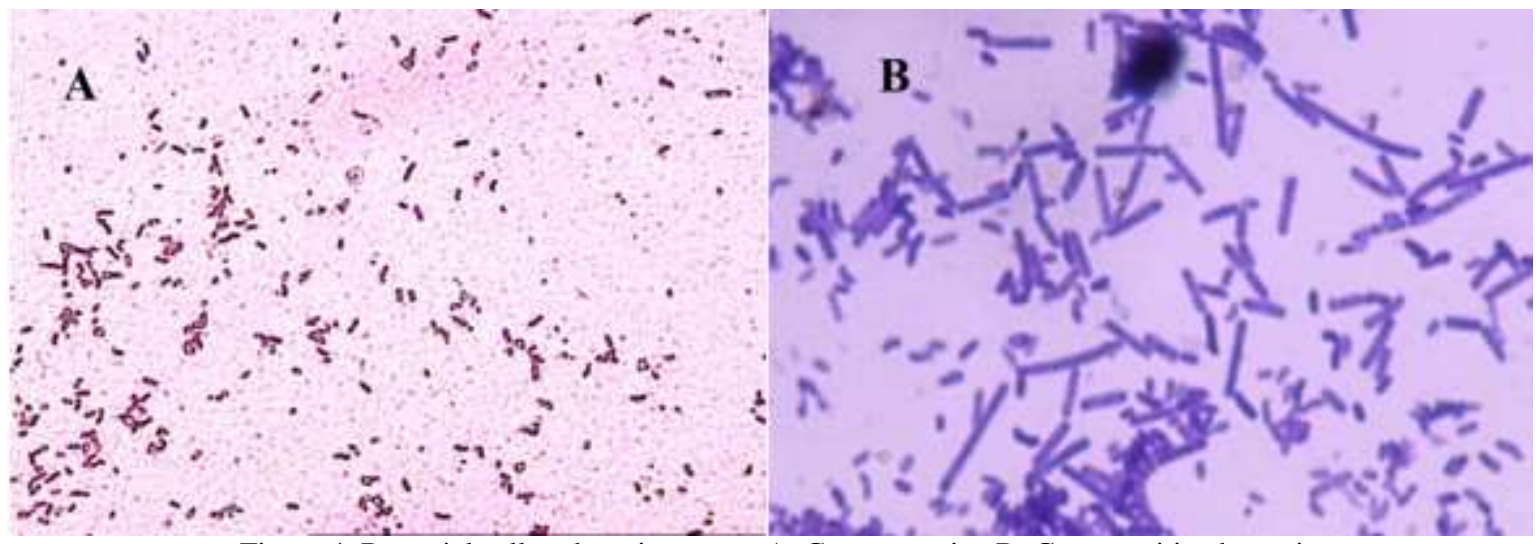

Figure 4. Bacterial cell under microscope A; Gram negative B; Gram positive bacteria.

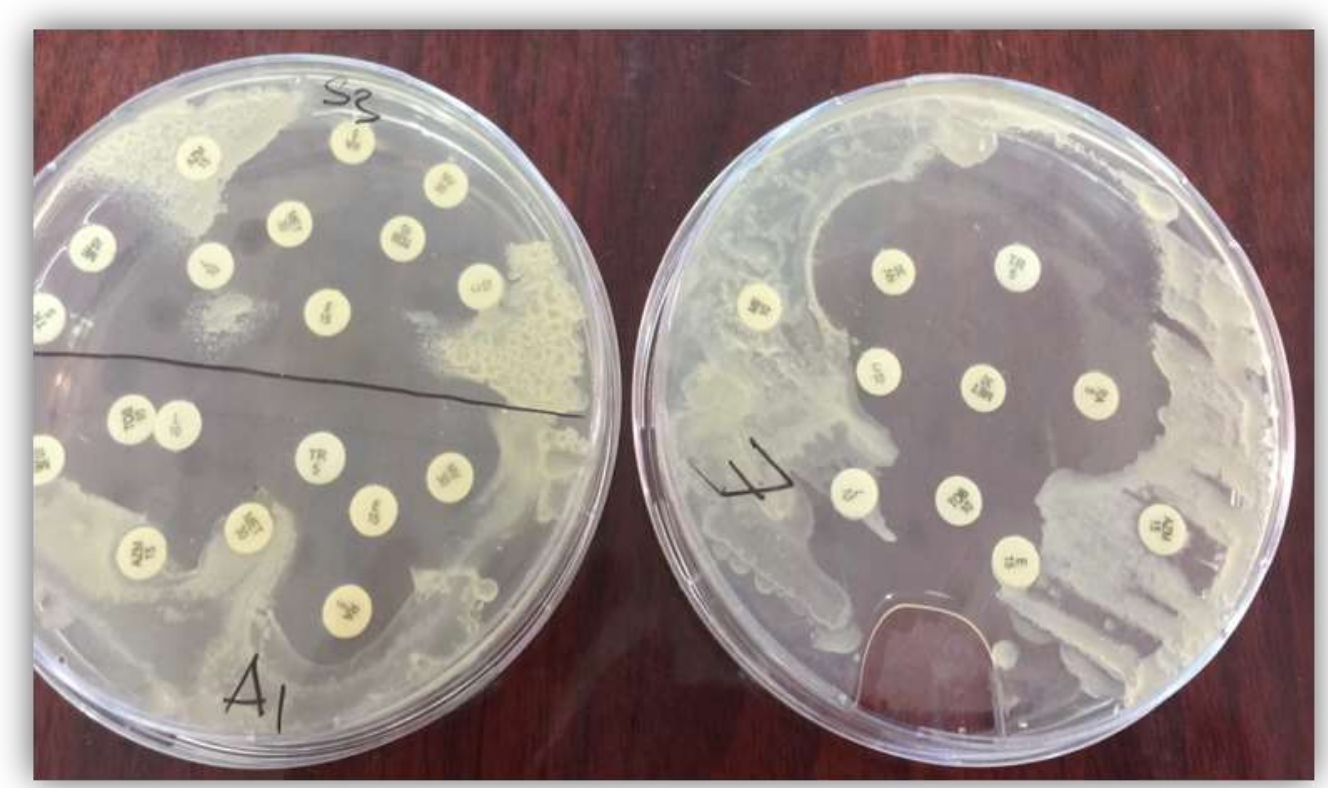

Figure 5.Antibiotic sensitivity of bacterial isolates showing zone of inhibition 
ISSN 2476-017X

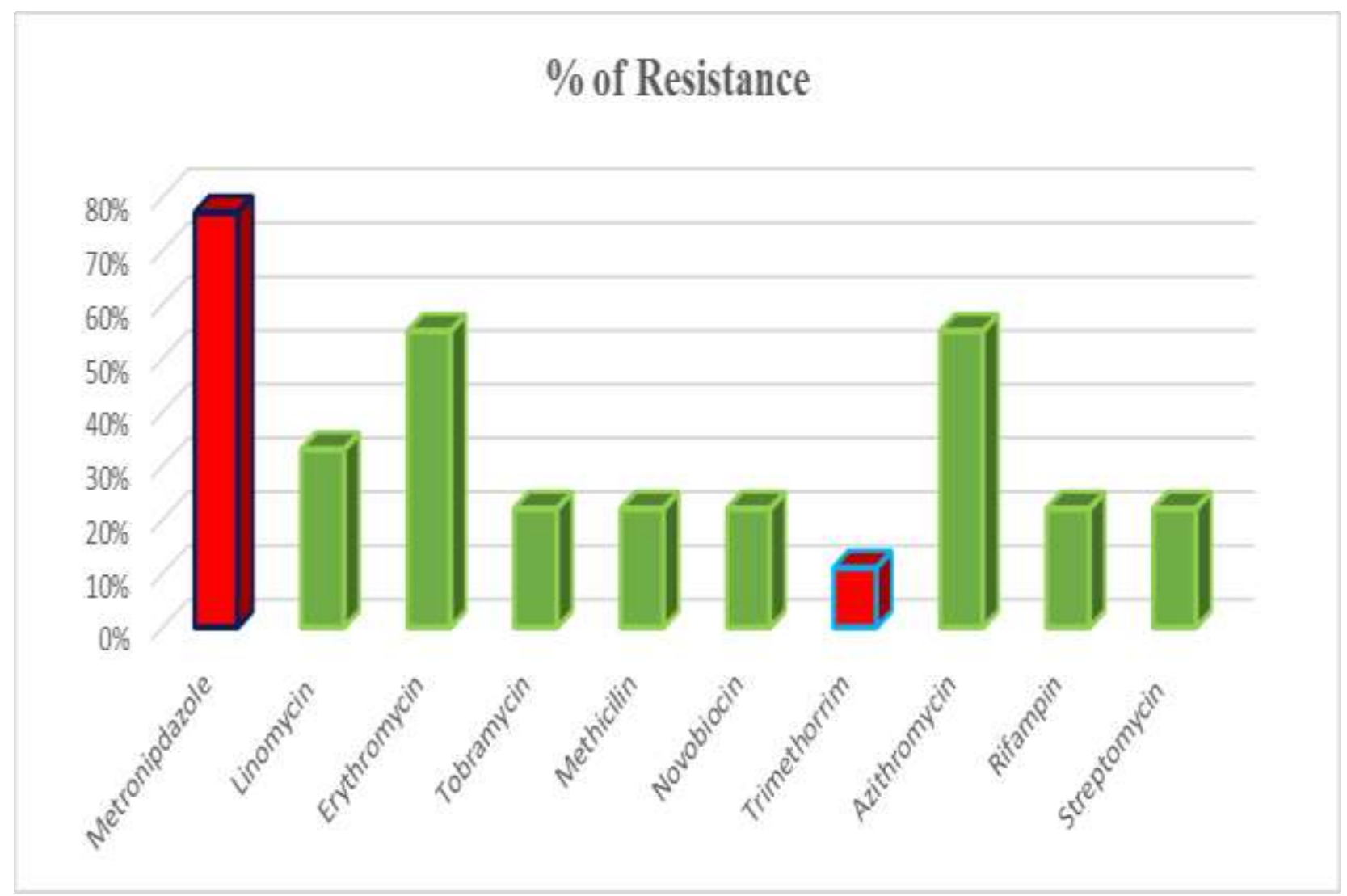

Figure 6 .Percent resistance of the bacterial isolates against antibiotics from computer keyboards 


\section{Global Proceedings Repository \\ American Research Foundation}

ISSN 2476-017X

Available online at http://proceedings.sriweb.org

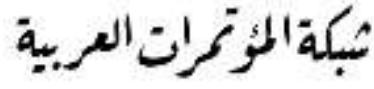

http://arab.kmshare.net/

ARF

References

1. Al- Ghamdi AK, Abdel Malik SMA, and ashshi AM, Faidah H, Shukri H, Jiman -Fatani AA.

Bacterial contamination of computer keyboards and mice, elevator buttons and shopping carts, J

Afr Micro Resear 2011; 5(23): 3998-4003.

2. P.P.T.L. Anastasiades, H. Rousseau, W.H. Steinberg and G. Jouberl staphylococcus aurous on computer mice and keyboards in intensive care units of the Universities' Academic hospital Bloemfontein and ICU staffs knowledge of its hazards and cleaning practices . African Journal of Epidemiology infection (2009).24:22-26.

3. Po. Liang, Lu, Iksin, Tun Chienchen, Li. Ngma. With clinical isolates. BMC. Infectious Diseases (200e). 164(e). Methicillin - resistant staphylococcus areus and interface surfaces of hospital wards and association

4. Palmer S, Bray S. (2001). Longitudinal study of computer usage in flexible engineering education. Aust J Educe Tech. 17(3): 313-329.

5. Onasanya SA The impact of computer in a developing country like Nigeria, Nigerian $\mathbf{J}$ Resea , Produ.2002; 1: 56-78 Hong DY, Park SO, Lee KP, Baek KJ, Moon HW ,Han SB etal ,Bacterial contamination of computer and hand hygiene compliance in the emergency department. $J$ emerg med. 2012; 19: 387-393.

6. Fleming Team. Computer Keyboards in Nursing and patient care. Manag Infect Control.2007; 48: 36-38.

7. Holt, J. G., N. R. Krieg, et al. (1994). “Bergey's manual of determinative bacteriology.

8. Bauer, A.W., et al. (1966) Antibiotic susceptibility testing by a standardized single disk method. American Journal of Clinical Pathology, 45, 493-496. 